\title{
The effect of climate change on the distribution of a tropical zoanthid (Palythoa caribaeorum) and its ecological implications
}

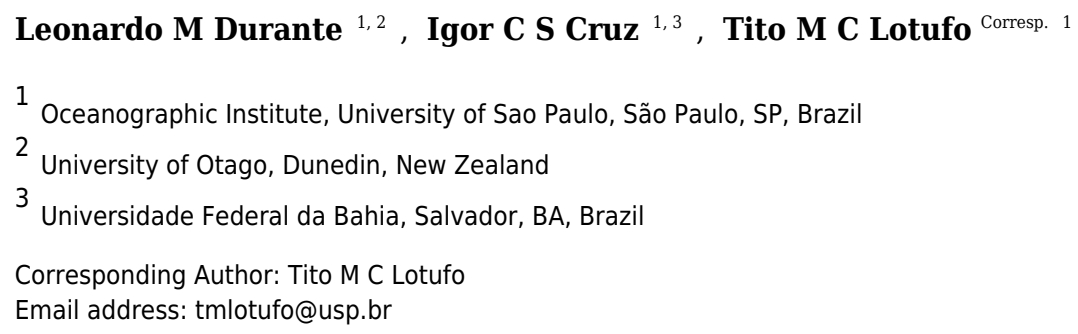

Palythoa caribaeorum is a zoanthid often dominant in shallow rocky environments along the west coast of the Atlantic Ocean, from the tropics to the subtropics. This species has high environmental tolerance and is a good space competitor in reef environments. Considering current and future scenarios in the global climate regime, this study aimed to model and analyze the distribution of $P$. caribaeorum, generating maps of potential distribution for the present and the year 2100. The distribution was modeled using maximum entropy (Maxent) based on 327 occurrence sites retrieved from the literature. Calcite concentration, maximum chlorophyll-a concentration, salinity, $\mathrm{pH}$, and temperature range yielded a model with the smallest Akaike information criterion (2649.8), and were used in the present and future distribution model. Data from the HadGEM2-ES climate model were used to generate the projections for the year 2100. The present distribution of $P$. caribaeorum shows that parts of the Brazilian coast, Caribbean Sea, and Florida are suitable regions for the species, as they are characterized by high salinity and $\mathrm{pH}$ and small temperature variation. An expansion of the species' distribution was forecast northward under mild climate scenarios, while a decrease of suitable areas was forecast in the south. In the climate scenario with the most intense changes, $P$. caribaeorum would lose one-half of its suitable habitats, including the northernmost and southernmost areas of its distribution. The Caribbean Sea and northeastern Brazil, as well as other places under the influence of coastal upwellings, may serve as potential havens for this species. 
1 The effect of climate change on the distribution of a tropical zoanthid (Palythoa

2 caribaeorum) and its ecological implications

3

4

5 Leonardo M. Durante ${ }^{1,2}$, Igor C. S. Cruz ${ }^{1,3}$, Tito M. C. Lotufo ${ }^{1}$,

6

7

8 'Oceanographic Institute, University of São Paulo, São Paulo, SP - Brazil

9 2University of Otago, Otago, Dunedin - New Zealand

$10{ }^{3}$ Universidade Federal da Bahia, Salvador, BA - Brazil

11

12 Corresponding author: Tito Lotufo, e-mail: tmlotufo@usp.br

13

14 


\section{Abstract}

Palythoa caribaeorum is a zoanthid often dominant in shallow rocky environments along the west coast of the Atlantic Ocean, from the tropics to the subtropics. This species has high environmental tolerance and is a good space competitor in reef environments. Considering current and future scenarios in the global climate regime, this study aimed to model and analyze the distribution of $P$. caribaeorum, generating maps of potential distribution for the present and the year 2100. The distribution was modeled using maximum entropy (Maxent) based on 327 occurrence sites retrieved from the literature. Calcite concentration, maximum chlorophyll- $a$ concentration, salinity, $\mathrm{pH}$, and temperature range yielded a model with the smallest Akaike information criterion (2649.8), and were used in the present and future distribution model. Data

27 from the HadGEM2-ES climate model were used to generate the projections for the year 2100. The present distribution of $P$. caribaeorum shows that parts of the Brazilian coast, Caribbean

29 Sea, and Florida are suitable regions for the species, as they are characterized by high salinity 30 and $\mathrm{pH}$ and small temperature variation. An expansion of the species' distribution was forecast

31 northward under mild climate scenarios, while a decrease of suitable areas was forecast in the

32 south. In the climate scenario with the most intense changes, $P$. caribaeorum would lose one-half 33 of its suitable habitats, including the northernmost and southernmost areas of its distribution. The

34 Caribbean Sea and northeastern Brazil, as well as other places under the influence of coastal 35 upwellings, may serve as potential havens for this species. 


\section{Introduction}

41

Palythoa caribaeorum (Duchassaing \& Michelotti, 1860) is a sessile colonial anthozoan

common along the west coast of the Atlantic Ocean (Kemp et al., 2006). This species can be found from Florida in the US (Kemp et al., 2006) to Arvoredo Island in Brazil (Bouzon, Brandini \& Rocha, 2012), as well as around many oceanic islands in the Atlantic, such as Bermuda (Lesser et al., 1990) and the São Pedro e São Paulo archipelago (Edwards \& Lubbock, 1983). Its distribution is not limited to the western side of the Atlantic Ocean, however; with records in the Cape Verde islands (Reimer, Hirose \& Wirtz, 2010). This broad geographic distribution is possible because $P$. caribaeorum has a great tolerance to a wide range of environmental conditions (Sebens, 1982). Although studies on P. caribaeorum larvae are lacking, it is expected that its biology would be similar to its sister species, Palythoa turbeculosa (Esper 1791), which has symbiotic larvae with planktonic habits and a larval stage up to 170 days long (Polak et al., 2011; Ryland, 1997).

It is found on hard bottom environments, from the intertidal zone to depths up to 12 meters (Sebens, 1982), where it can be dominant (Monteiro et al., 2008). Colonies have a mat format usually occupying large areas along the substratum (Sebens, 1982; Acosta, 2001; Silva et al., 2015). The animal's color varies from yellow and brown to bronze, easily identifiable in the field (Fig. 1a).

P. caribaeorum is a mixotrophic organism, hosting symbiotic dinoflagellates (Symbiodinium) inside its tissues (Sebens, 1977; Suchanek \& Green, 1981) and feeding on 
61 planktonic organisms, which contributes to the energy flux from plankton to benthic

62 environments (Sorokin, 1991; Santana et al., 2015). Few studies have highlighted the importance

63 of $P$. caribaeorum in association with other invertebrates (Pérez, Vila-Nova \& Santos, 2005),

64 reef dynamics (Silva et al., 2015), or the enrichment of the bottom fish community (Mendonça-

65 Neto et al., 2008). However, a study conducted in the Todos os Santos Bay in Brazil (Cruz et al.,

66 2015b) showed that the increased abundance of Palythoa spp. decreased habitat heterogeneity,

67 and consequently the richness of fish and benthic organisms, changing the local trophic structure

68 in that region.

69 P. caribaeorum is capable of overgrowing and thus adversely affecting the growth and

70 recruitment of several organisms (Suchanek \& Green, 1981; Castro et al., 2012), such as hard

71 corals, hydrocorals, and other zoanthids, showing great efficiency competing for space. $P$.

72 caribaeorum also has a fast growth rate estimated to vary between $0.04-0.15 \mathrm{~mm}$ per day

73 (Bastidas \&Bone, 1996; Silva et al., 2015). In general, zoanthids can dominate in areas where the

74 environmental factors make it difficult for the settlement of scleractinian corals (Fautin, 1988;

75 Cruz et al., 2015a), often becoming important as the main benthic component (Mendonça-Neto

76 et al., 2008) and nursery habitat for other invertebrates (Pérez, Vila-Nova \& Santos, 2005).

77 Suchanek and Green (1981) and Sebens (1982) claimed that predation does not seem to be an

78 ecological element controlling the distribution and abundance of $P$. caribaeorum, probably due

79 to defense strategies related to nematocysts and palytoxin that are found in the animal's tissue

80 (Hines \& Pawlik, 2011). However, Stampar et al. (2007) reported a case of a Hawksbill turtle,

81 Eretmochelys imbricata, preying colonies of $P$. caribaeorum in southeastern Brazil.

82 Regarding its ecological role, investigating the current and future distribution of $P$.

83 caribaeorum will yield a prognosis of areas likely to experience changes in their benthic 
84 communities because of the presence or absence of $P$. caribaeorum. Assessing how species and

85 biological systems are affected by climate change as well as the generation of forecast models

86 are increasingly needed by decision makers and environmental managers (Gutt et al., 2012).

87 Species distribution models (SDM) are largely used in ecology, biogeography, and conservation biology to help solve practical problems in these fields (Guisan \& Thuiller, 2005;

89 Elith et al., 2011; Acosta et al., 2016). One of the main assumptions of SDM is that the

90 environment is in equilibrium with its species, whose distribution is determined by

91 environmental variability (Araújo \& Pearson, 2005), excluding biological interactions, dispersion

92 barriers, and fast or small-scale environmental disturbances (De Marco, Diniz-Filho \& Bini,

93 2008). Temporal and climatic variations also interfere in the modeling, and environmental data

94 must be gathered from the same period in which the species was recorded, making it difficult to

95 acquire large amounts of data for mobile organisms. In this scenario, P. caribaeorum is a good

96 candidate for the use of SDM.

The accelerating rates of environmental change pose a challenge to most organisms living

98 in shallow waters throughout the world's oceans. At a global scale, between 1971 and 2010, the

99 warming rate of the oceans' surface waters reached $0.13^{\circ} \mathrm{C}$ per decade (IPCC, 2014). Since 1950 ,

100 coastal regions with high evaporation rates are becoming saltier; and for the same period, the $\mathrm{pH}$

101 of surface waters has decreased by 0.1 (IPCC, 2014). The forecast for the year 2050 shows a

102 redistribution of marine organisms as a function of the increase in temperature. This

103 redistribution is expected to be toward mid-latitude zones, increasing species richness in these

104 areas while decreasing richness in the tropics due to extinction, migration, and reduction in

105 genetic diversity (Fields et al., 1993). However, it is still unknown for sure how the effects of 
106 climate change, at the population level, will affect the environment at large ecological scales

107 (Harley et al., 2006; Thomas et al., 2017).

108 This study aimed to investigate and model the distribution of $P$. caribaeorum along the

109 western coast of the Atlantic Ocean, generating potential distribution maps for the present and

110 the year 2100 based on forecast climate models. The maps were used to characterize the species'

111 habitat and identify areas where suitability was retained, lost, or gained for P. caribaeorum over

112 time and under different climate scenarios.

113

\section{Materials and Methods}

2.1. Study area

The study area comprised the western Atlantic Ocean (from $-42.5^{\circ}$ to $42.5^{\circ}$ latitude),

118 between 2 meters of altitude and 100 meters of depth (Fig. 1b), hence extending beyond the

119 current known distribution of $P$. caribaeorum. The oceanographic features of this region are

120 influenced by the South Equatorial Current, from the east, which is divided into two components:

121 northward (North Brazil Current) and southward along the coast (Brazil Current). The North

122 Brazil Current flows toward the northwest, passing by the Caribbean Sea, Yucatan Channel, and

123 Gulf of Mexico before merging with the Antilles Current in the Florida Strait to form the Gulf

124 Stream, which flows toward Europe. Due to the strong tropical component, the region between

$12520^{\circ} \mathrm{S}$ and $30^{\circ} \mathrm{N}$ is strongly influenced by waters heated in equatorial regions (Ekman, 1953). In

126 contrast, regions closer to the boundaries of this study are influenced by both tropical and colder

127 currents, such as the Slopewater Current from the Labrador Current in the north (Churchill \&

128 Berger, 1998) and the Malvinas Current in the south (Talley et al., 2011). The study region is 
129 also influenced by large river discharges, mainly from the La Plata, Amazon, Orinoco,

130 Mississippi, and Saint Lawrence rivers (Fig. 1b).

131

2.2. Biological data mining and filtering

An extensive literature review was performed to obtain the largest possible number of

134 studies with occurrence data for P. caribaeorum (Supporting information 1). Occurrence data

135 recorded by the authors of this study and from global databases, such as WORMS, OBIS, and

136 GBIF, were also used, totaling 327 occurrence points for the species. The three identified

137 synonyms (Reimer, 2015)_Palythoa caribaea Duerden, 1898, Palythoa caribbaea Goreau,

138 1959, and Palythoa caribdea Carballeira et al., 1998 — were included.

139 Occurrence points found on land or at depths deeper than 100 meters were automatically

140 excluded, as were those localized in freshwater environments. Because sampled areas and

141 methodologies varied among study sites, only one occurrence per pixel ( 5 arcminutes), based on

142 the environmental variables dataset, was kept for analysis (Elith \& Leathwick, 2009). This point

143 was placed in the middle of each pixel, disregarding the exact occurrence point. After that, to

144 avoid bias originating from densely sampled sites, the geographic filter "OccurrenceThinner"

145 version 1.04 (Verbruggen, 2012), with thresholds of 0.5 and 1, was used, resulting in the final

146 dataset.

147

\subsection{Selecting environmental variables, the RMvalue, and the running Maxent} Environmental and bathymetric data, with resolutions of 5 and 1 arcminute, were

150 obtained from the Bio-Oracle (Tyberghein et al., 2012) dataset and the ETOPO1 Global Relief

151 Model, respectively (Amante \& Eakins, 2009). Twenty-seven layers of environmental data and 
152 their transformations available on the Bio-Oracle dataset were used in the analyses (Table 1).

153 Each layer was cropped using ArcGIS 10.2 to only include areas within 2 meters altitude and 154100 meters depth.

155 The habitat modeling was done using the Maxent 3.3.3 program (Phillips, Anderson \&

156 Schapire, 2006). Maxent has the advantage of using only occurrence points, instead of

157 occurrence and absence/pseudo-absence, considering the lack of this type of data, especially for

158 marine organisms. Maxent also demonstrates good performance identifying suitable habitats

159 (Phillips, Anderson \& Schapire, 2006; Reiss et al., 2011; Meißner et al., 2014) and predicting

160 novel distributions for species (Costa et al., 2012; Acosta et al., 2016) when compared with other

161 software.

162 All the features available in Maxent were used during the modeling (standard set up). To

163 choose the environmental variables and the regulation multiplier $(R m)$ value, the

164 "MaxentVariableSelection" package (Jueterbock, 2016) for R 3.3.1 (R Core Team, 2015) was

165 used, with a contribution threshold of $4 \%$ and Pearson's correlation coefficient of 0.9 . A series of

166 runs were conducted, varying the $R m$ from 0.5 to 10 with increments of 0.5 , and were then

167 assessed using the Akaike Information Criterion (AIC). The environmental variables and $R m$ of

168 the model with a lower AIC were used to run the final Maxent model. The AIC tends to choose

169 models that sort the most important variables, as well as models that better estimate

170 environmental suitability (Warren et al., 2014), and therefore behave better when projected onto

171 novel climate scenarios than models chosen using the Area Under the Receiver Operator Curve

172 (AUC) value (Warren \& Seifert, 2011). The AIC selects the optimal and most parsimonious

173 model, taking into account its complexity (Bozdogan, 1987). Thirty percent of the data were

174 randomly sampled to test the model along each of the 100 replicates, resulting in an average for 
175 all replicates. In all the analyses, 10,000 random points were used as the background along the

176 whole study area.

177

178

\subsection{Climate model data}

179

Data from the HadGEM2-ES model (Collins et al., 2011) retrieved from the Coupled

180

Model Intercomparison Project (CMIP5) were used on the projections for the year 2100 under

181 three different Representative Concentration Pathway (RCP) climate scenarios: low, middle, and high radiative forcing of 2.6, 4.5, and $8.5 \mathrm{~W} / \mathrm{m}^{2}$, respectively (Van Vuuren et al., 2011). The RCPs are related to retention of energy by the Earth's surface due to accumulation of greenhouse gases from human activities, therefore higher numbers represent a greater anthropogenic impact on our biosphere. The HadGEM2-ES climate model was freely available and provided outputs of the main interest variables and high resolution in tropical areas under the RCP climate scenarios.

187 When there were no available data for the projections, the layers were kept unchanged. NetCDF

188 files from the climate model were interpolated using the bilinear interpolation "interp2" of

189 Matlab 7.14, and were then cropped and converted to ASC format.

Projecting the results onto maps

Maps were generated using the cumulative likelihood of species occurrence obtained

193 from Maxent, which can be interpreted as the sum of the relative occurrence rate of the species in

194 one pixel and other pixels with the same or lower values of the relative occurrence rate (ROR).

195 This type of output is best for drawing species distribution boundaries for different climate

196 scenarios (Merow, Smith \& Silander, 2013) and also has a better visual presentation. For the

197 binary maps, the threshold equal to the maximum sensitivity plus specificity (max SSS) was 
198 chosen to detect suitable habitats for P. caribaeorum. This threshold improves the distinction

199 between occurrence and absence sites, as well as between occurrence and background, also

200 selecting the same threshold for both occurrence-only and occurrence-absence models (Liu,

201 Newell \& White, 2015).

202 Because $P$. caribaeorum is distributed along coastal zones, the final results were cropped 203 to depths up to 30 meters, better defining its real habitat. The map of the Marine Ecoregions of 204 the World (Spalding et al., 2007) was used as a reference for the results and discussion of 205 specific areas (Fig. 2).

206

207

\section{Results}

208

209

After filtering, 135 occurrence points of P. caribaeorum were kept for the analyses (Fig.

210 2). The model with a lower AIC (2649.8) presented an $R m$ of 3.5 and showed good performance

211 defining occurrence and absence sites for $P$. caribaeorum (AUC $=0.860 \pm 0.023$ ) (Swets, 1988).

212 The difference between the test AUC and the train AUC yielded a value of 0.015 , showing that

213 the model was not over-adjusted and is transferable to novel climate scenarios (Jueterbock et al.,

214 2016; Warren \& Seifert, 2011).

215 The environmental variables that contributed the most to the model were salinity

216 (47.9\%), concentration of calcite (21\%), maximum concentration of chlorophyll- $a(13.3 \%), \mathrm{pH}$

$217(9.2 \%)$, and temperature range (8.5\%), and were therefore kept in the model (Table 1). The

218 habitat of $P$. caribaeorum is characterized by salinity values higher than 34 , a maximum

219 chlorophyll- $a$ concentration from 0 to $28 \mathrm{mg} / \mathrm{m}^{3}$, a $\mathrm{pH}$ higher than 7.85 , and temperature

220 variation up to $10^{\circ} \mathrm{C}$, although these intervals become much narrower when variable correlations 
221 are considered. For calcite, the model pointed to a modulating influence, as no minimum or

222 maximum values were indicated.

223 The output of the HadGEM2-ES climate model for salinity, $\mathrm{pH}$, and temperature (used to

224 calculate temperature range) was used to project the SDM model to novel scenarios for the year

2252100 , while calcite and chlorophyll- $a$ were kept constant. A max SSS equal to 25.97 was used as

226 a threshold to infer suitable areas, thus identifying the potential distribution of the species.

227 Five hundred forty eight square kilometers were characterized as currently suitable for $P$.

228 caribaeorum (Fig. 3). Under the RCP 2.6 scenario (Fig. 4), the southern range of P. caribaeorum

229 distribution would lose suitability, as would the Caribbean, Bermudan, and Floridian regions;

230 however, the total suitable area is close to the one observed for the present: $492,000 \mathrm{~km}^{2}$. An

231 increase in suitable areas in the Guianan, Amazonian, Bahamian, and Caribbean regions was also

232 observed, but the biggest change occurred in the northern part of its distribution, in the northern

233 Gulf of Mexico and along the Carolinian and Virginian regions. In these areas, the potential

234 distribution of the species reached almost as far north as Chesapeake Bay. The southernmost area

235 capable of retaining suitability for the species was near Cape Frio, in southeastern Brazil.

236 The projection under RCP 4.5 (Fig. 5) also shows that part of the Brazilian coast would

237 lose habitat suitability, only remaining suitable around the Abrolhos Bank and in northeastern

238 Brazil. In the north, the species' potential distribution is similar to the 2.6 scenario, only

239 presenting smaller suitable areas in those regions, $470,000 \mathrm{~km}^{2}$ in total.

240 Under the scenario with the higher anthropogenic impact, RCP 8.5 (Fig. 6), almost the

241 entire potential distribution for P. caribaeorum along the Brazilian coast would be lost, including

242 the northeast region. Under RCP 8.5, the anthozoan would also lose suitable habitats in regions

243 around Florida, the northern Gulf of Mexico, and the eastern and western Caribbean. 
Overall, for this climate scenario, only one-half of the suitable areas seen in the present,

245

246

around $275,000 \mathrm{~km}^{2}$, were characterized as a potential habitat for the species, comprising the southern, western, and southwestern Caribbean, the southern Gulf of Mexico, and the Bahamian, Greater Antilles, and eastern Brazil regions. Nevertheless, under the RCP 8.5 scenario, there would be an increase in suitable areas in the southwestern Caribbean, along Nicaragua's coast, similar to the RCP 4.5 forecast (Fig. 5).

To demonstrate the most important regions for the species, a map of the intersection of all suitable areas under any climate scenarios for the year 2100 was made (Fig. 7). Figure 7 shows that the northern part of the map (from $0^{\circ}$ northward) would have much more significance for the potential distribution of $P$. caribaeorum than the southern part. The suitable areas comprise six ecoregions in the north (southern, southwestern, and western Caribbean, southern Gulf of Mexico, and Bahamian and Greater Antilles regions) against only two in the south (northeastern and eastern Brazil).

\section{Discussion}

\subsection{Environmental variables and $\mathrm{P}$. caribaeorum's habitat}

The variables selected to model $P$. caribaeorum's habitat suitability are in line with those used in studies about environmental controls for other anthozoans. For instance, temperature and salinity are two of the most important factors shaping the growth of modern reefs (Wood, 1993). Temperature is also related to coral (Hoegh-Guldberg, 1999; Hughes et al., 2003; Villamizar et al., 2008) and P. caribaeorum bleaching (Kemp et al., 2006). Variation in salinity may induce osmotic stress and can alter the zonation of zoanthids, including P. caribaeorum (Sebens, 1982). Changes in chlorophyll- $a$ concentrations can also play a role in the distribution of $P$. 
268

269

270

271

272

273

274

275

276

277

278

279

280

281

282

283

284

285

286

287

288

289

290

caribaeorum due to its heterotrophic nutrition and dependency on the water column productivity, unlike most coral reef species, which depend solely on autotrophy and therefore, clear

oligotrophic waters. This species also seems to be affected by lower $\mathrm{pH}$ (Kroeker et al., 2013), which is another consequence of global environmental changes (Okazaki et al., 2017).

When the projection of the habitat suitability of P. caribaeorum for the present (Fig. 3) is compared with the map of the biggest river discharges in the study area (Fig. 1), it becomes evident that salinity has a major influence on the distribution of this species. Salinity had a higher contribution to the model, sometimes reducing habitat suitability even when the values of other variables, like temperature and chlorophyll- $a$, were adequate for the species. Freshwater discharges from rivers are also an important source of calcite for oceans; however, calcite is 100 times more soluble in seawater than in freshwater (Libes, 2009), so high concentrations of this mineral are not limited to river-influenced regions. In fact, regarding only calcite, habitat suitability is positively correlated with its concentration, possibly because calcite concentration also indicates other important biogeochemical controls.

The maximum concentration of chlorophyll- $a$ presented a distribution pattern similar to calcite and was also strongly affected by coastal processes, mainly big river discharges, which fertilize the sea and enhance primary production. From satellite data, chlorophyll- $a$ cannot be distinguished from dissolved organic matter (DOM) without an algorithm specific to each region (Ali et al., 2016; Liew et al., 2001; Vazyulya et al., 2014). Away from river discharges,

chlorophyll- $a$ can be re-suspended back into the water column by wind, currents, and waves, and is therefore correlated with suspended sediment (Walsh, Dieterle \& Esaias, 1987). The values of chlorophyll- $a$ data used in this study are relative to its maximum concentration over several years. Hence, it is likely that these values are the sum of all processes listed above: river 
291 discharge, new production, and re-suspension. P. caribaeorum inhabits coastal regions with high

292 chlorophyll- $a$ concentrations, but when these concentrations are related to river discharge, the

293 regions lose habitat suitability due to lower salinity and $\mathrm{pH}$ values. This can indicate that despite

294 the low salinity, chlorophyll- $a$ and turbidity can be important factors for the species' niche. This

295 information corroborates previous studies (Segal \& Castro, 2011; Steiner et al., 2015), which

296 suggested that low salinity was an exclusion factor for P. caribaeorum. However, it is difficult to

297 decouple the influence of variables related to water quality from demands related more to depth

298 and substrate in coastal areas, as both are intrinsically linked in continental shores. For instance,

299 P. caribaeorum is quite abundant around remote oceanic islands where eutrophication, turbidity,

300 and other processes typical of continental shores are not present. However, P. caribaeorum

301 seems to be more common in regions influenced by coastal processes with high turbidity along

302 the Brazilian coast (Cruz, personal observation).

303 Similar to calcite and chlorophyll- $a$, $\mathrm{pH}$ has a strong coastal component related to

304 salinity, especially around the Amazonian river mouth, where $\mathrm{pH}$ drops below 7 , and in the

305 Virginian and Carolinian regions, where values exceed 8.25- both regions are devoid of the

306 anthozoan. Regarding $\mathrm{pH}$ alone, a habitat with a pH over 7.85 is considered suitable, but due to

307 correlations with the other variables, the habitat of $P$. caribaeorum is constrained to a $\mathrm{pH}$

308 between 8.05 and 8.25 .

309 Lastly, temperature range seems to influence the species in a typical latitudinal fashion,

310 presenting higher values in the northernmost and southernmost regions of the study area due to

311 the intrusion of colder waters onto the continental shelf at higher latitudes. Although $P$.

312 caribaeorum exhibits high tolerance to changes in temperature and water properties in tide pool

313 environments (Bastidas \& Bone, 1996) and in southeastern Brazil (Bouzon, Brandini \& Rocha, 
314 2012), extreme variations in temperature and decreases in salinity caused by rain can cause

315 mortality (Sebens, 1977). For current environmental conditions, the latitudes $30^{\circ}$ North and $30^{\circ}$

316 South can be recognized as limits to the distribution of this organism, mainly due to the

317 temperature range: between $9^{\circ} \mathrm{C}$ and $13^{\circ} \mathrm{C}$ in the south and $13^{\circ} \mathrm{C}$ and $24^{\circ} \mathrm{C}$ in the north. In these

318 regions, salinity reaches a value of 34, with high seasonal variation (Piola et al., 2000;

319 Rasmussen et al., 2005).

320

\subsection{Present distribution of P. caribaeorum}

322

There are regions characterized as potential habitats for P. caribaeorum that have no

323 record of the species (Fig. 2 and 3). This indicates either a lack of adequate sampling effort in the

324 Guianan, Greater Antilles, Bahamian, and western and southwestern Caribbean regions, the

325 absence of proper substrata, or other conditions not considered in the present modeling.

326 In general, the region between Florida and the Yucatan Peninsula, with the exception of

327 Flower Garden Banks off the coast of Texas (Tester et al., 2013), is characterized by the absence

328 of coral reefs due to low temperatures during winter and high rainfall (Longhurst, 2007). In

329 shallow areas in the northern Gulf of Mexico previously dominated by corals and sponges,

330 changes in temperature and an increase in river discharge were followed by a community shift

331 around 2005, and these areas are now dominated by algae (DeBose et al., 2013). This

332 information corroborates our model predictions for $P$. caribaeorum in that region, strongly

333 influenced by the Mississippi River Delta.

334 Using Briggs and Bowen's (2012) classification, it is evident that all of P. caribaeorum's

335 current potential habitat is within warm marine provinces, characterizing the species' distribution

336 as tropical. However, the limits of its distribution are close to warm-temperate and cold 
337 provinces, which are characterized as marginal parts of the distribution. Studying reef

338 communities located at higher latitudes can improve our knowledge of how this species will be

339 affected during environmental and climatic changes (Thomas et al., 2017); thus, examining $P$.

340 caribaeorum's distribution in these regions is extremely important.

341

342

343

4.3 Palythoa caribaeorum's response to climate change in the year 2100

344 in salinity of 2.5 in the northern Gulf of Mexico, Virginian, and Carolinian regions, in turn

345 increasing habitat suitability for P. caribaeorum (Fig. 4). Along the southeastern Brazilian coast,

346 salinity would drop by 0.3 , sufficient to become an unsuitable area for the species. Changes

347 would also be seen in the plume of the Amazon river, influencing adjacent coastal regions to a

348 lesser degree.

349 Values of $\mathrm{pH}$ in the year 2100 would drop for all regions, which is one of the factors that

350 could exclude $P$. caribaeorum. Since the anthozoan response to changes in $\mathrm{pH}$ is related to

351 salinity, its northernmost distribution should increase due to a weaker influence of rivers and a

352 decline in the temperature range under the RCP 2.6 scenario. On the other hand, decreases in

353 salinity and $\mathrm{pH}$ and more intense temperature fluctuations in the southeast and east of Brazil

354 would result in a loss of suitable areas, except along the coast of Cape Frio in southeastern

355 Brazil. This result may be associated with upwelling in this region (Castro et al., 2006), which

356 modifies water characteristics and reduces the frequency of osmotic and thermal stress on the

357 species (Hu \& Guillemin, 2016), making that region more suitable for the animal. The same

358 process seems to occur along the coast of Colombia, as seen for coral species in that region 
359 (Chollet, Mumby \& Cortés, 2010). The Colombian coast is very important for P. caribaeorum

360 since it would remain a suitable habitat under any climate scenario (Fig. 7).

361 The same trend observed under the RCP 2.6 scenario occurs in the RCP 4.5 scenario,

362 with an increase in potential habitat in the northernmost range of its distribution (Fig. 5).

363 However, for this scenario, P. caribaeorum would also lose habitat in the south, including

364 around Cape Frio. Other areas, such as the continental shelf of the Yucatan Peninsula, would

365 gain suitable zones in the RCP 4.5 scenario, due to higher salinity values and lower temperature

366 variations. For regions experiencing a loss of suitable areas, such as the northeastern Brazil and

367 Amazonian regions, the drop in $\mathrm{pH}$ values, salinity, and an increase in the temperature range

368 would be responsible.

369 As expected, the climate scenario with the strongest anthropogenic impact, RCP 8.5, 370 presented the smallest suitable area for the species (Fig. 6). Although it presented smaller

371 temperature fluctuations compared to other scenarios, in the RCP 8.5 scenario P. caribaeorum

372 would lose potential habitats in both the northernmost and southernmost ranges of its

373 distribution, without any gain in suitable areas due to a drastic decrease in salinity and $\mathrm{pH}$ values.

374 Freshwater intrusions from the La Plata and Amazon rivers would influence the species' habitat

375 along the Brazilian shelf, restricting its distribution to northeastern Brazil. Similarly, the

376 Mississippi River plume would decrease the adequacy for the species in the north. In general,

377 when looking at changes in salinity, $\mathrm{pH}$, and temperature for any climate scenario, the variations

378 are more intense in the north and south via the intrusion of polar and temperate currents into the

379 continental shelf. These differences alter the habitat of $P$. caribaeorum and are more prominent 380 in the Southern Hemisphere. 
Mexico, the Bahamas, the Greater Antilles, and northeastern and eastern Brazil would retain

the species under adverse environmental conditions (Haffer, 1969). Except for the Brazilian

their distributions restricted toward this diversity-gathering hotspot in the Atlantic Ocean.

\subsection{Likely changes in reef communities}

Studies have shown that $P$. caribaeorum coexists with many other organisms, especially

401 algae such as Caulerpa racemosa var. peltata, Bryopsis spp. (Magalhães et al., 2015),

402 Sargassum, Halimeda, Laurencia, Dictyota, Dictyopteris, Ulva, and coralline algae (Steiner et

403 al., 2015). Macroalgae are common in coral reefs, sometimes dominating the community and 
404 competing for space with corals (Tanner, 1995; Bruno et al., 2009). The disappearance of $P$.

405 caribaeorum from many Brazilian reefs in the Abrolhos Bank would imply a change in the reef

406 communities. It is possible that with the vanishing of $P$. caribaeorum, colonization of the

407 available space would first be by algae, most likely cyanobacteria, due to their fast growth rate,

408 especially in nutrient-poor environments (Villaça \& Pitombo, 1997). However, the composition

409 of the new community will depend on multiple factors, from changes in recruitment rates,

410 growth, and mortality to changes in nutrient concentrations and herbivory (Littler, Littler \&

411 Taylor, 1983; Sandin \& McNamara, 2012); community resilience is another factor (Roff \&

412 Mumby, 2012).

413 Regarding the colonization of new areas by P. caribaeorum, the temperate region of the

414 northwestern Atlantic would see its suitable area increased under RCP 2.6 and 4.5, around Cape

415 Hatteras and Chesapeake Bay. Zoanthids have the potential to disperse to great distances due to

416 their long larval stage (Ryland et al., 2000; Polak et al., 2011) and asexual reproduction (Acosta,

417 Sammarco \& Duarte, 2005), alongside their potential to raft on floating objects and boats (Santos

418 et al., 2016). Thus, it is possible that the colonization of $P$. caribaeorum in the northwestern

419 Atlantic would occur under these climate scenarios for hard bottom environments.

420 Nicaragua's coast, which is part of the southwestern Caribbean region, was particularly

421 important for the species due to the increase in potential habitat area under RCP 4.5 and 8.5 (Fig.

4225 and 6). Few studies were conducted about the benthic community in that region, which

423 presents high coverage of algae of the genera Dictyota and Padina, corals such as Orbicella

424 annularis, Agaricia spp., Porites spp., Acropora palmata, and Millepora alcicornis, and lower

425 coverage of sponge and soft corals (Kramer et al., 2000). The same study discusses the

426 likelihood of a phase shift in the coming years due to natural disturbances and climate change. 
427 Phase shifts from reef-building corals to zoanthids were previously reported in the western

428 Atlantic (Cruz et al., 2015a), where they reduced fish diversity associated with the reefs (Cruz et

429 al., 2015b), and have the potential to adversely affect regional fisheries and tourism, which are

430 main income sources for the local populatio.

431 Although it was assumed in this work, it is not expected that all individuals will be

432 affected in the same way by climate change. It is known that, at smaller scales, differences

433 between symbiont algae (Kemp et al., 2006), as well as the anthozoan's plasticity (Costa et al.,

434 2011), can result in distinct outcomes for different populations under climate change. Average

435 and maximum temperatures had small contributions to the model and were not considered here;

436 however, it is known that surface waters are likely to experience an increase in temperature,

437 especially in tropical areas (IPCC, 2014). The ability to endure such changes will also play a role

438 in P. caribaeorum's distribution. The authors highlight here the importance of future

439 experimental work on temperature stress on key organisms, such as $P$. caribaeorum, to better

440 understand the future of tropical reef communities.

441 It is possible that, due to the scale of the problem, some local variations were not

442 accounted for, such as the discharge of small rivers around the Gulf of Mexico region. Smaller

443 scales and regional studies should use higher resolution data for this matter. Sea level rise can

444 modify wave stress atop coral reefs, favoring the colonization of $P$. caribaeorum over other

445 organisms, including zoanthids (Rabelo et al., 2015). This effect was not considered in this study

446 because the IPCC forecast for sea level rise did not surpass 0.8 meters, which is smaller than the

447 error of the bathymetric data used in this work.

448

449 5. Conclusions 
The present habitat of $P$. caribaeorum can be characterized by high salinity values, marine

$452 \mathrm{pH}$, and a small to moderate range of temperature in coastal and shallow environments. The

453 species' current distribution in the western Atlantic Ocean is restricted to warm provinces,

454 identifying it as a coastal and warm-water species, together with shallow water corals. According

455 to this study, this organism's potential distribution is likely to change by the year 2100 . It is

456 possible that, under low to mild anthropogenic impacts (RCP 2.6 and 4.5), the species'

457 distribution will be extended northward and will face a decrease of suitable habitat in the

458 southernmost range of its distribution under any climate scenario. Under the scenario with the

459 highest anthropogenic impacts (RCP 8.5), novel suitable areas poleward were not predicted, and

460 only one-half of its potential habitat area would be retained when compared to the present. Under

461 any climate scenario, the Caribbean Sea remained suitable for the species, characterizing this

462 region as a possible refuge. Upwelling regions, such as Cape Frio and northern Colombia, could

463 provide a refuge for this species as well, diminishing the local impacts of climate changes.

464 Although community changes were discussed according to the available literature, biological and

465 oceanographic processes not considered in this study may play an important role in the outcome 466 of these changes.

467

468

469 Acknowledgments

470

We thank our colleagues Paulo Polito, André Acosta, Romina Barbosa, Bruno Ferrero,

472 and Alexander Jueterbock, each of whom provided advice and expertise that contributed to this 
473 work. We would also like to thank Ana Flora Sarti for kindly providing part of the data used in 474 this work, as well as Erica Donlon for the English review. This work is also a product of the 475 SISBIOTA-Mar research network.

476

477

\section{References}

478

479

480

481

482

483

484

485

486

487

488

489

490

491

492

493

494

495

Acosta A. 2001. Disease in Zoanthids: Dynamics in space and time. Hydrobiologia 460:113130. DOI: $10.1023 / \mathrm{A}: 1013135702430$.

Acosta AL., Giannini TC., Imperatriz-Fonseca VL., Saraiva AM. 2016. Worldwide Alien Invasion: A Methodological Approach to Forecast the Potential Spread of a Highly Invasive Pollinator. Plos One 11:e0148295. DOI: 10.1371/journal.pone.0148295.

Acosta A., Sammarco PW., Duarte LF. 2005. New Fission Processes in the Zoanthid Palythoa caribaeorum: Description and Quantitative Aspects. Bulletin of Marine Science 76:1-26.

Ali KA., Ortiz J., Bonini N., Shuman M., Sydow C. 2016. Application of Aqua MODIS sensor data for estimating chlorophyll $a$ in the turbid Case 2 waters of Lake Erie using bio-optical models. GIScience \& Remote Sensing 53:483-505. DOI: 10.1080/15481603.2016.1177248.

Amante C., Eakins BW. 2009. ETOPO1 1 Arc-Minute Global Relief Model: Procedures, Data Sources and Analysis. NOAA Technical Memorandum NESDIS NGDC-24:19. DOI: 10.1594/PANGAEA.769615.

Araújo MB., Pearson RG. 2005. Equilibrium of species' distribution with climate. Ecography 28:693-695.

Bastidas C., Bone D. 1996. Competitive Strategies Between Palythoa Caribaeorum and Zoanthus Sociatus (Cnidaria: Anthozoa) at a Reef Flat Environment in Venezuela. Bulletin of Marine Science 59:543-555. 
496 Bouzon JL., Brandini FP., Rocha RM. 2012. Biodiversity of Sessile Fauna on Rocky Shores of

497 Coastal Islands in Santa Catarina, Southern Brazil. Marine Science 2:39-47. DOI:

498 10.5923/j.ms.20120205.01.

499

Bozdogan H. 1987. Model selection and Akaike's information criterion (AIC): the general theory and its analytical extensions. 52:345-370.

501

502

Briggs JC., Bowen BW. 2012. A realignment of marine biogeographic provinces with particular reference to fish distributions. Journal of Biogeography 39:12-30. DOI: 10.1111/j.13652699.2011.02613.x.

504

Briggs JC., Bowen BW. 2013. Marine shelf habitat: biogeography and evolution. Journal of Biogeography 40:1023-1035. DOI: 10.1111/jbi.12082.

Bruno JF., Sweatman H., Precht WF., Selig ER., Schutte VGW. 2009. Assessing evidence of 507 phase shifts from coral to macroalgal dominance on coral reefs. Ecology 90:1478-1484. DOI: $10.1890 / 08-1781.1$.

Castro BM., Brandini FP., Pires-Vanin AMS., Miranda LB. 2006. Multidisciplinary

510 Oceanography Processes on the Western Atlantic Continental Shelf Between $4^{\circ} \mathrm{N}$ and $34^{\circ} \mathrm{S}$.

511 In: Robinson AR, Brink KH eds. The Sea: The Global Coastal Ocean. Harvard University, $512 \quad 259-295$.

513 Castro CB., Segal B., Negrão F., Calderon EN. 2012. Four-year monthly sediment deposition on 514 turbid southwestern Atlantic coral reefs, with a comparison of benthic assemblages.

515 Brazilian Journal of Oceanography 60:49-63. DOI: 10.1590/S1679-87592012000100006.

516 Chollet I., Mumby PJ., Cortés J. 2010. Upwelling areas do not guarantee refuge for coral reefs in 517 a warming ocean. Marine Ecology Progress Series 416:47-56. DOI: 10.3354/meps08775.

518 Churchill JH., Berger TJ. 1998. Transport of Middle Atlantic Bight shelf water to the Gulf 

10.1029/98JC01628.

521 Collins WJ., Bellouin N., Doutriaux-Boucher M., Gedney N., Halloran P., Hinton T., Hughes J., 522 Jones CD., Joshi M., Liddicoat S., Martin G., O ’connor F., Rae J., Senior C., Sitch S., 523 Totterdell I., Wiltshire A., Woodward S. 2011. Geoscientific Model Development 524 Development and evaluation of an Earth-System model - HadGEM2. Geosci. Model Dev 525 4:1051-1075. DOI: 10.5194/gmd-4-1051-2011.

Costa DL., Gomes PB., Santos AM., Valenca NS., Vieira N a., Perez CD. 2011. Morphological plasticity in the reef zoanthid Palythoa caribaeorum as an adaptive strategy. Annales Zoologici Fennici 48:349-358. DOI: 10.5735/086.048.0602.

Costa BM., Kendall MS., Parrish FA., Boland RC., Lecky J., Spalding H. 2012. Prediction of 530 Mesophotic Coral Distributions in the Au'au Channel, Hawaii.

531 Cruz ICS., de Kikuchi RKP., Longo LL., Creed JC. 2015a. Evidence of a phase shift to 532 Epizoanthus gabrieli Carlgreen, 1951 (Order Zoanthidea) and loss of coral cover on reefs in 533 the Southwest Atlantic. Marine Ecology 36:318-325. DOI: 10.1111/maec.12141.

534 Cruz ICS., Loiola M., Albuquerque T., Reis R., de Anchieta C. C. Nunes J., Reimer JD., 535 Mizuyama M., Kikuchi RKP., Creed JC. 2015b. Effect of Phase Shift from Corals to 536 Zoantharia on Reef Fish Assemblages. Plos One 10:e0116944. DOI: 10.1371/journal.pone.0116944.

DeBose JL., Nuttall MF., Hickerson EL., Schmahl GP. 2013. A high-latitude coral community with an uncertain future: Stetson Bank, northwestern Gulf of Mexico. Coral Reefs 32:255267. DOI: $10.1007 / \mathrm{s} 00338-012-0971-3$.

541 Edwards A., Lubbock R. 1983. The ecology of Saint Paul's Rocks (Equatorial Atlantic). Journal 
of Zoology 200:51-69. DOI: 10.1111/j.1469-7998.1983.tb06108.x.

543 Ekman S. 1953. Zoogeography of the sea. London: Sidgwick \& Jackson.

544 Elith J., Leathwick JR. 2009. Species Distribution Models: Ecological Explanation and

545 Prediction Across Space and Time. Annu Rev Ecol Syst 40:415-436. DOI:

$546 \quad$ 10.1146/annurev.ecolsys.1.

547 Elith J., Phillips SJ., Hastie T., Dudík M., Chee YE., Yates CJ. 2011. A statistical explanation of 548 MaxEnt for ecologists. Diversity and Distributions 17:43-57. DOI: 10.1111/j.14724642.2010.00725.x.

550 Fautin DG. 1988. Anthozoan dominated benthic environments. In: Proceedings of the 6th $551 \quad$ International Coral Reef Symposium, Australia. 1-6.

552 Fields PA., Graham JB., Rosenblatt RH., Somero GN. 1993. Effects of expected global climate 553 change on marine faunas. Trends in ecology \& evolution (Personal edition) 8:361-367.

554 DOI: $10.1016 / 0169-5347(93) 90220-J$.

555 Guisan A., Thuiller W. 2005. Predicting species distribution: Offering more than simple habitat 556 models. Ecology Letters 8:993-1009. DOI: 10.1111/j.1461-0248.2005.00792.x.

557 Gutt J., Zurell D., Bracegridle TJ., Cheung W., Clark MS., Convey P., Danis B., David B., De 558 Broyer C., di Prisco G., Griffiths H., Laffont R., Peck LS., Pierrat B., Riddle MJ., Saucède 559 T., Turner J., Verde C., Wang Z., Grimm V. 2012. Correlative and dynamic species 560 distribution modelling for ecological predictions in the Antarctic: A cross-disciplinary $561 \quad$ concept. Polar Research 31:1-23. DOI: 10.3402/polar.v31i0.11091.

562 Haffer J. 1969. Speciation in amazonian forest birds. Science (New York, N.Y.) 165:131-7. DOI: $563 \quad 10.1126 /$ science. 165.3889 .131$.

564 Harley CDG., Hughes AR., Kristin M., Miner BG., Sorte CJB., Carol S., Randall Hughes a., 
565 Hultgren KM., Thornber CS., Rodriguez LF., Tomanek L., Williams SL. 2006. The impacts

566 of climate change in coastal marine systems. Ecology letters 9:228-41. DOI:

$567 \quad$ 10.1111/j.1461-0248.2005.00871.x.

568 Hines DE., Pawlik JR. 2011. Assessing the antipredatory defensive strategies of Caribbean non-

569 scleractinian zoantharians (Cnidaria): is the sting the only thing? Marine Biology 159:389-

570 398. DOI: $10.1007 / \mathrm{s} 00227-011-1816-2$.

571 Hoegh-Guldberg O. 1999. Climate change, coral bleaching and the future of the world's coral

572 reefs. Marine Freshwater Research 50:839-866. DOI: 10.1071/MF99078.

573 Hu Z-M., Guillemin M-L. 2016. Coastal upwelling areas as safe havens during climate warming.

574 Journal of Biogeography:1-2. DOI: 10.1111/jbi.12887.

575 Hughes TP., Baird AH., Bellwood DR., Card M., Connolly SR., Folke C., Grosberg R., Hoegh-

576 Guldberg O., Jackson JBC., Kleypas J., Lough JM., Marshall P., Nystrom M., Palumbi SR.,

577 Pandolfi JM., Rosen B., Roughgarden J. 2003. Climate Change, Human Impacts, and the

578 Resilience of Coral Reefs. Science 301:929-934. DOI: 10.1126/science.1085046.

579 IPCC. 2014. Climate Change 2014: Synthesis Report. Contribution of Working Groups I, II and

$580 \quad$ III to the Fifth Assessment Report of the Intergovernmental Panel on Climate Change.

581 Jueterbock A. 2016. Package "MaxentVariableSelection": Selecting the Best Set of Relevant

582 Environmental Variables along with the Optimal Regularization Multiplier for Maxent

$583 \quad$ Niche Modeling.

584 Kemp DW., Cook CB., LaJeunesse TC., Brooks WR. 2006. A comparison of the thermal

585 bleaching responses of the zoanthid Palythoa caribaeorum from three geographically

586 different regions in south Florida. Journal of Experimental Marine Biology and Ecology

587 335:266-276. DOI: 10.1016/j.jembe.2006.03.017. 
588 Kramer P., Kramer PR., Arias-Gonzalez E., McField M. 2000. Status of coral reefs of Northern

589 Central America: Mexico, Belize, Guatemala, Honduras, Nicaragua and El Salvador.

590 Kroeker KJ., Kordas RL., Crim R., Hendriks IE., Ramajo L., Singh GS., Duarte CM., Gattuso

591 JP. 2013. Impacts of ocean acidification on marine organisms: Quantifying sensitivities and 592 interaction with warming. Global Change Biology 19:1884-1896. DOI: 10.1111/gcb.12179.

593 Lesser MP., Stochaj WR., Tapley DW., Shick JM. 1990. Bleaching in coral reef anthozoans:

594 effects of irradiance, ultraviolet radiation, and temperature on the activities of protective

595 enzymes against active oxygen. Coral Reefs 8:225-232. DOI: 10.1007/BF00265015.

596 Libes SM. 2009. Calcite, Alkalinity, and the $\mathrm{pH}$ of Seawater. In: Introduction to Marine

597 Biogeochemistry. Academic Press, 909.

598 Liew SC., Chia AS., Kwoh LK. 2001. Evaluating the validity of SeaWiFS chlorophyll algorithm 599 for coastal waters. In: Proc. 22nd Asian Conference on Remote Sensing. 1-5.

600 Littler M., Littler D., Taylor P. 1983. Evolutionary stragegies in a tropical barrier reef system:

601 functional-form groups of marine macroalgae. Deep Sea Research Part B. Oceanographic

602 Literature Review 30:935. DOI: 10.1016/0198-0254(83)96598-6.

603 Liu C., Newell G., White M. 2015. On the selection of thresholds for predicting species

604 occurrence with presence-only data. Ecology and Evolution:337-348. DOI:

$605 \quad 10.1002 /$ ece 3.1878.

606 Longhurst AR. 2007. Ecological Gepgraphy of the Sea. Academic Press.

607 Magalhães GM., Amado-Filho GM., Rosa MR., de Moura RL., Brasileiro PS., De Moraes FC.,

608 Francini-Filho RB., Pereira-Filho GH. 2015. Changes in benthic communities along a 0-60

609 m depth gradient in the remote St. Peter and St. Paul Archipelago (Mid-Atlantic Ridge,

610 Brazil). Bulletin of Marine Science 91:377-396. DOI: 10.5343/bms.2014.1044. 
611 De Marco P., Diniz-Filho JA., Bini LM. 2008. Spatial analysis improves species distribution 612 modelling during range expansion. Biol Lett 4:577-580. DOI: 10.1098/rsbl.2008.0210.

613 Meißner K., Fiorentino D., Schnurr S., Martinez Arbizu P., Huettmann F., Holst S., Brix S., 614 Svavarsson J. 2014. Distribution of benthic marine invertebrates at northern latitudes - An 615 evaluation applying multi-algorithm species distribution models. Journal of Sea Research 616 85:241-254. DOI: 10.1016/j.seares.2013.05.007.

617 Mendonça-Neto JP., Ferreira CEL., Chaves LCT., Pereira RC. 2008. Influence of Palythoa 618 caribaeorum (Anthozoa, Cnidaria) zonation on site-attached reef fishes. Anais da Academia 619 Brasileira de Ciencias 80:494-513. DOI: 10.1590/S0001-37652008000300010.

620 Merow C., Smith MJ., Silander JA. 2013. A practical guide to MaxEnt for modeling species' 621 distributions: what it does, and why inputs and settings matter. Ecography 36:1058-1069.

622 DOI: 10.1111/j.1600-0587.2013.07872.x.

623 Monteiro J., Almeida C., Freitas R., Delgado A., Porteiro F., Santos R. 2008. Coral assemblages

624 of Cabo Verde : preliminary assessment and description. Proccedings of the 11th International Coral Reef Symposium-2008:1416-1419.

626 Okazaki RR., Towle EK., van Hooidonk R., Mor C., Winter RN., Piggot AM., Cunning R., 627 Baker AC., Klaus JS., Swart PK., Langdon C. 2017. Species-specific responses to climate 628 change and community composition determine future calcification rates of Florida Keys 629 reefs. Global Change Biology 23:1023-1035. DOI: 10.1111/gcb.13481.

630 Onken R. 1994. The Asymmetry of Western Boundary Currents in the Upper Atlantic Ocean.

631 Journal of Physical Oceanography 24:928-948. DOI: 10.1175/1520-

632 0485(1994)024<0928:TAOWBC>2.0.CO;2.

633 Pérez CD., Vila-Nova D a., Santos a. M. 2005. Associated community with the zoanthid 
634 Palythoa caribaeorum (Duchassaing \& Michelotti, 1860) (Cnidaria, Anthozoa) from littoral 635 of Pernambuco, Brazil. Hydrobiologia 548:207-215. DOI: 10.1007/s10750-005-5441-2.

636 Phillips SJ., Anderson RP., Schapire RE. 2006. Maximum entropy modeling of species

637 geographic distributions. Ecological Modelling 190:231-259. DOI:

$638 \quad$ 10.1016/j.ecolmodel.2005.03.026.

639 Piola AR., Campos EJD., MÖller Jr OO., Charo M., Martinez C. 2000. Subtropical Shelf Front 640 off eastern South America. Jornal of Geouphysical Research 105:6565-6578.

641 Polak O., Loya Y., Brickner I., Kramarski-Winter E., Benayahu Y. 2011. The widely-distributed 642 Indo-Pacific Zoanthid Palythoa tuberculosa: a sexually conservative strategist. Bulletin of 643 marine science 87:605-621. DOI: 10.5343/bms.2010.1088.

644 Rabelo EF., Soares M de O., Bezerra LEA., Matthews-Cascon H. 2015. Distribution pattern of 645 zoanthids (Cnidaria: Zoantharia) on a tropical reef. Marine Biology Research 11:584-592. $646 \quad$ DOI: $10.1080 / 17451000.2014 .962542$.

647 Rasmussen LL., Gawarkiewicz G., Owens WB. 2005. Slope water, Gulf Stream, and seasonal 648 influences on southern Mid-Atlantic Bight circulation during the fall-winter transition. 649 Journal of Geophysical Research 110:1-16. DOI: 10.1029/2004JC002311.

650 Reimer J. 2015. Palythoa caribaeorum (Duchassaing \& Michelotti, 1860)

651 Reimer JD., Hirose M., Wirtz P. 2010. Zoanthids of the Cape Verde Islands and their symbionts: 652 previously unexamined diversity in the Northeastern Atlantic. Contributions to Zoology $653 \quad 79: 147-163$.

654 Reiss H., Cunze S., König K., Neumann H., Kröncke I. 2011. Species distribution modelling of 655 marine benthos : a North Sea case study. Marine Ecology Progress Series 442:71-86. DOI: $656 \quad 10.3354 /$ meps09391. 
657 Rocha LA., Rocha CR., Robertson DR., Bowen BW.2008. Comparative phylogeography of

658 Atlantic reef fishes indicates both origin and accumulation of diversity in the Caribbean. 659 BMC Evolutionary Biology 8:157. DOI: 10.1186/1471-2148-8-157.

660 Roff G., Mumby PJ. 2012. Global disparity in the resilience of coral reefs. Trends in Ecology 661 and Evolution 27:404-413. DOI: 10.1016/j.tree.2012.04.007.

662 Ryland JS. 1997. Reproduction in Zoanthidea (Anthozoa: Hexacorallia). Invertebrate 663 Reproduction \& Development 31:177-188. DOI: 10.1080/07924259.1997.9672575.

664 Ryland JS., De Putron S., Scheltema RS., Chimonides PJ., Zhadan DG. 2000. Semper's 665 (zoanthid) larvae: pelagic life, parentage and other problems. Hydrobiologia 440:191-198.

666 Sandin SA., McNamara DE. 2012. Spatial dynamics of benthic competition on coral reefs.

667 Oecologia 168:1079-90. DOI: 10.1007/s00442-011-2156-0.

668 Santana EFC., Alves AL., Santos ADM., Cunha MDGGS., Perez CD., Gomes APB. 2015.

669 Trophic ecology of the zoanthid Palythoa caribaeorum (Cnidaria: Anthozoa) on tropical

670 reefs. Marine Biological Association of the United Kingdom 95:301-309. DOI:

$671 \quad 10.1017 / \mathrm{S} 0025315414001726$.

672 Santos MEA., Kitahara MV., Lindner A., Davis Reimer J. 2016. Overview of the order

673 Zoantharia (Cnidaria: Anthozoa) in Brazil. Marine Biodiversity 46:547-559. DOI:

$674 \quad 10.1007 / \mathrm{s} 12526-015-0396-7$.

675 Sebens K. 1977. Autotrophic and heterotrophic nutrition of coral reef zoanthids. In: Proceedings 676 of the 3rd International Coral Reef Symposium. 397-404.

677 Sebens KP. 1982. Intertidal distribuition of Zoanthids on the Caribbean Coast of Panamá: Effects 678 of predation and desiccation. Bulletin of Marine Science 32:316-335.

679 Segal B., Castro CB. 2011. Coral community structure and sedimentation at different distances 
682 Silva JF., Gomes PB., Santana EC., Silva JM., Lima ÉP., Santos AMM., Pérez CD. 2015.

683 Growth of the tropical zoanthid Palythoa caribaeorum (Cnidaria: Anthozoa) on reefs in

684 northeastern Brazil. Anais da Academia Brasileira de Ciências 87:00-00. DOI:

$685 \quad 10.1590 / 0001-3765201520140475$.

686 Sorokin YI. 1991. Biomass, metabolic rates and feeding of some common reef zoantharians and 687 octocorals. Australian Journal of Marine and Freshwater Research 42:729-741. DOI: $688 \quad$ 10.1071/MF9910729.

689 Spalding MD., Fox HE., Allen GR., Davidson N., Ferdaña Z a., Finlayson M., Halpern BS., 690 Jorge M A., Lombana A., Lourie S A., Martin KD., Mcmanus E., Molnar J., Recchia C A., 691 Robertson J. 2007. Marine Ecoregions of the World: A Bioregionalization of Coastal and $692 \quad$ Shelf Areas. BioScience 57:573. DOI: 10.1641/B570707.

693 Stampar SN., Silva PF., Luiz Jr. OJ. 2007. 2007. Predation on the Zoanthid Palythoa 694 caribaeorum (Anthozoa, Cnidaria) by a Hawksbill Turtle (Eretmochelys imbricata) in 695 Southeastern Brazil. Marine Turtle Newsletter 117: 3.

696 Steiner AQ., Amaral FMD., Amaral JRBC., Sassi R., Barradas JI. 2015. Zonação de recifes 697 emersos da Área de Proteção Ambiental Costa dos Corais, Nordeste do Brasil. Iheringia. 698 Série Zoologia 105:184-192. DOI: 10.1590/1678-476620151052184192.

699 Suchanek TH., Green DJ. 1981. Interspecific competition between Palythoa caribaeorum and 700 other sessile invertebrates on St. Croix Reefs, U.S Virgin Islands. Proceedings of the 4th $701 \quad$ International Coral Reef Symposium 2:679-684.

702 Swets JA. 1988. Measuring the accuracy of diagnostic systems. Science (New York, N.Y.) 
240:1285-1293. DOI: 10.1126/science.3287615.

704 Talley LD., Pickard GL., Emery WJ., Swif JH. 2011. Atlantic Ocean. In: Descriptive Physical

$705 \quad$ Oceanography. Elsevier, 555.

706 Tanner JE. 1995. Competition between scleractinian corals and macroalgae: An experimental

707 investigation of coral growth, survival and reproduction. Journal of Experimental Marine

708 Biology and Ecology 190:151-168. DOI: 10.1016/0022-0981(95)00027-o.

709 Tester PA., Vandersea MW., Buckel CA., Kibler SR., Holland WC., Davenport ED., Clark RD.,

710 Edwards KF., Taylor JC., Pluym JL Vander., Hickerson EL., Litaker RW. 2013.

711 Gambierdiscus (Dinophyceae) species diversity in the Flower Garden Banks National

712 Marine Sanctuary, Northern Gulf of Mexico, USA. Harmful Algae 29:1-9. DOI:

$713 \quad$ 10.1016/j.hal.2013.07.001.

714 Thomas L., Kennington WJ., Evans RD., Kendrick GA., Stat M. 2017. Restricted gene flow and

715 local adaptation highlight the vulnerability of high-latitude reefs to rapid environmental

716 change. Global Change Biology 23:2197-2205. DOI: 10.1111/gcb.13639.

717 Tyberghein L., Verbruggen H., Pauly K., Troupin C., Mineur F., De Clerck O. 2012. Bio-

718 ORACLE: a global environmental dataset for marine species distribution modelling. Global

719 Ecology and Biogeography 21:272-281. DOI: 10.1111/j.1466-8238.2011.00656.x.

720 Vazyulya S., Khrapko A., Kopelevich O., Burenkov V., Eremina T., Isaev A. 2014. Regional

721 algorithms for the estimation of chlorophyll and suspended matter concentration in the Gulf

722 of Finland from MODIS-Aqua satellite data. Oceanologia 56:737-756. DOI:

$723 \quad$ 10.5697/oc.56-4.737.

724 Verbruggen H. 2012. OccurrenceThinner version 1.04.

725 Villaça R., Pitombo FB. 1997. Benthic communities of shallow-water reefs of abrolhos, brazil. 
Revista brasileira de oceanografia 45:35-43.

727 Villamizar E., Camisotti H., Rodríguez B., Pérez J., Romero M. 2008. Impacts of the 2005

728 Caribbean bleaching event at Archipiélago de Los Roques National Park, Venezuela.

729 Revista de biología tropical 56:255-270.

730 van Vuuren DP., Edmonds J., Kainuma M., Riahi K., Thomson A., Hibbard K., Hurtt GC., Kram

731 T., Krey V., Lamarque J-F., Masui T., Meinshausen M., Nakicenovic N., Smith SJ., Rose

732 SK.2011. The representative concentration pathways: an overview. Climatic Change 109:5-

733

31. DOI: $10.1007 / \mathrm{s} 10584-011-0148-\mathrm{z}$.

734 Walsh JJ., Dieterle DA., Esaias WE. 1987. Satellite detection of phytoplankton export from the 735 mid-Atlantic Bight during the 1979 spring bloom. Deep-Sea Research 34:675-703.

736 Warren DL., Seifert SN. 2011. Ecological niche modeling in Maxent: the importance of model 737 complexity and the performance of model selection criteria. 21:335-342.

738 Warren DL., Wright AN., Seifert SN., Shaffer HB. 2014. Incorporating model complexity and 739 spatial sampling bias into ecological niche models of climate change risks faced by 90

740 California vertebrate species of concern. Diversity and Distributions 20:334-343. DOI:

$741 \quad$ 10.1111/ddi.12160.

742 Wood R. 1993. Nutrients, predation and the History of Reef-Building. Society of Sedimentary $743 \quad$ Geology 8:526-543. 


\section{Figure 1}

Study area and major currents and rivers.

Underwater picture of (a) a Palythoa caribaeorum colony and (b) the study area (gray) with main rivers (black), adapted from the map "World Major Rivers" from ESRI; the schema of the main cold surface currents (gray) and warm surface currents (black) is adapted from Talley et al. (2011). Photo credit: Leonardo Durante. 


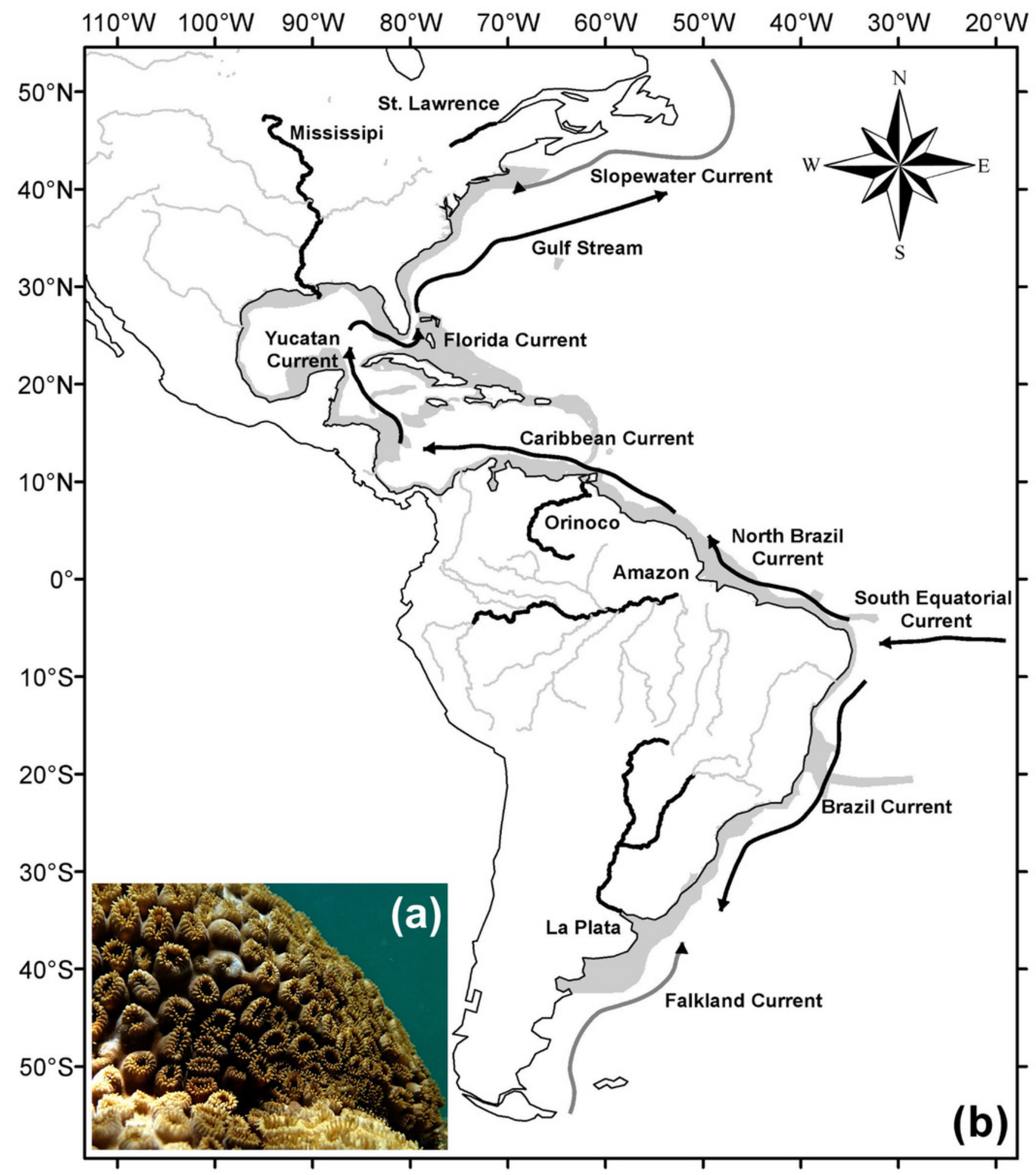


Figure 2

Occurrence points and Marine Ecoregions included in the study area

Study area and occurrence points of $P$. caribaeorum after filtering, with the Marine Ecoregions of the World as a reference (Spalding et al., 2007). 


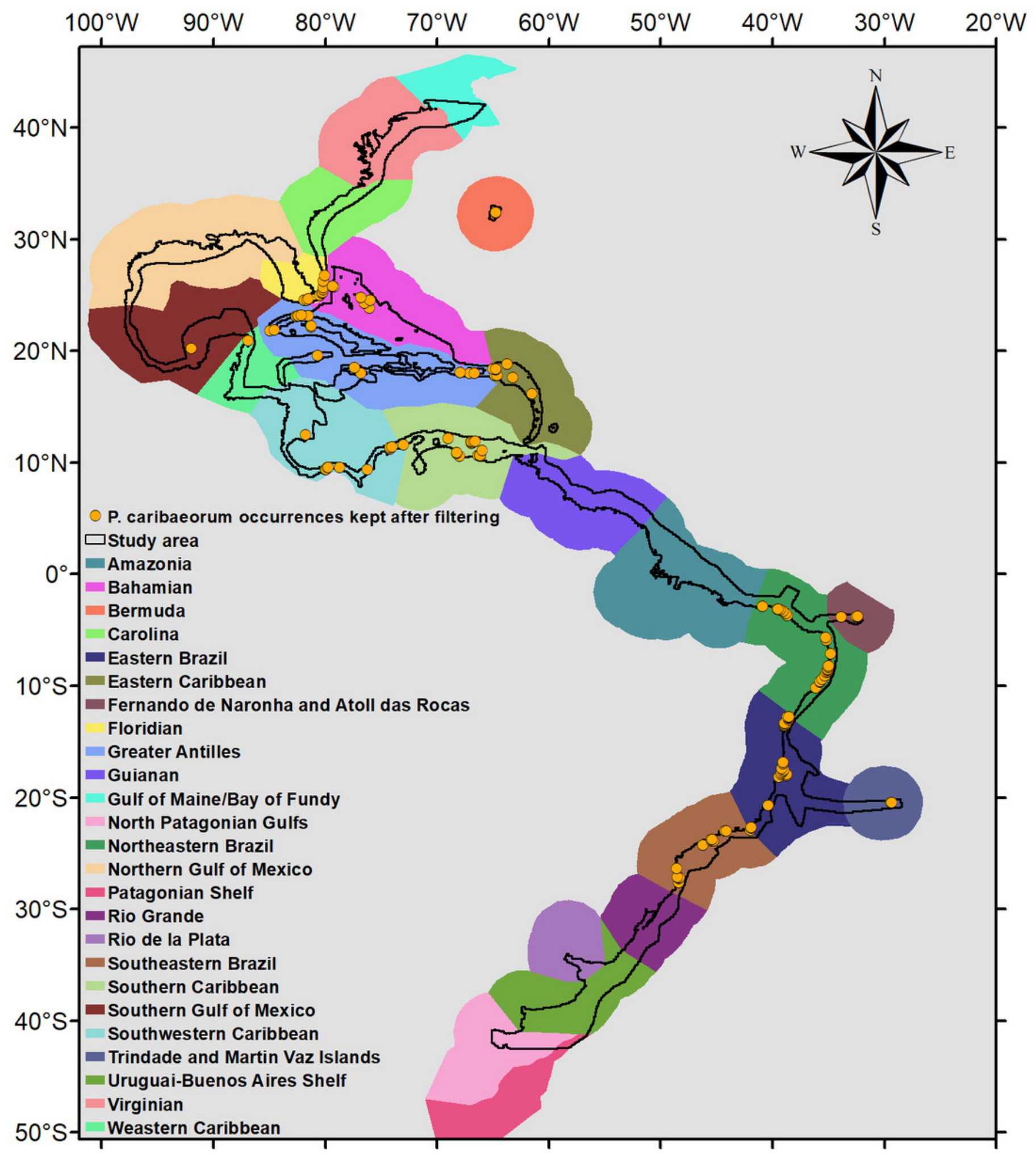


Figure 3

Suitable habitat for $P$. caribaeorum in the present

Details for (a) southeastern Brazil, (b) southern Gulf of Mexico, (c) southwestern Caribbean, (d) southern Caribbean, and (e) Floridian regions. 


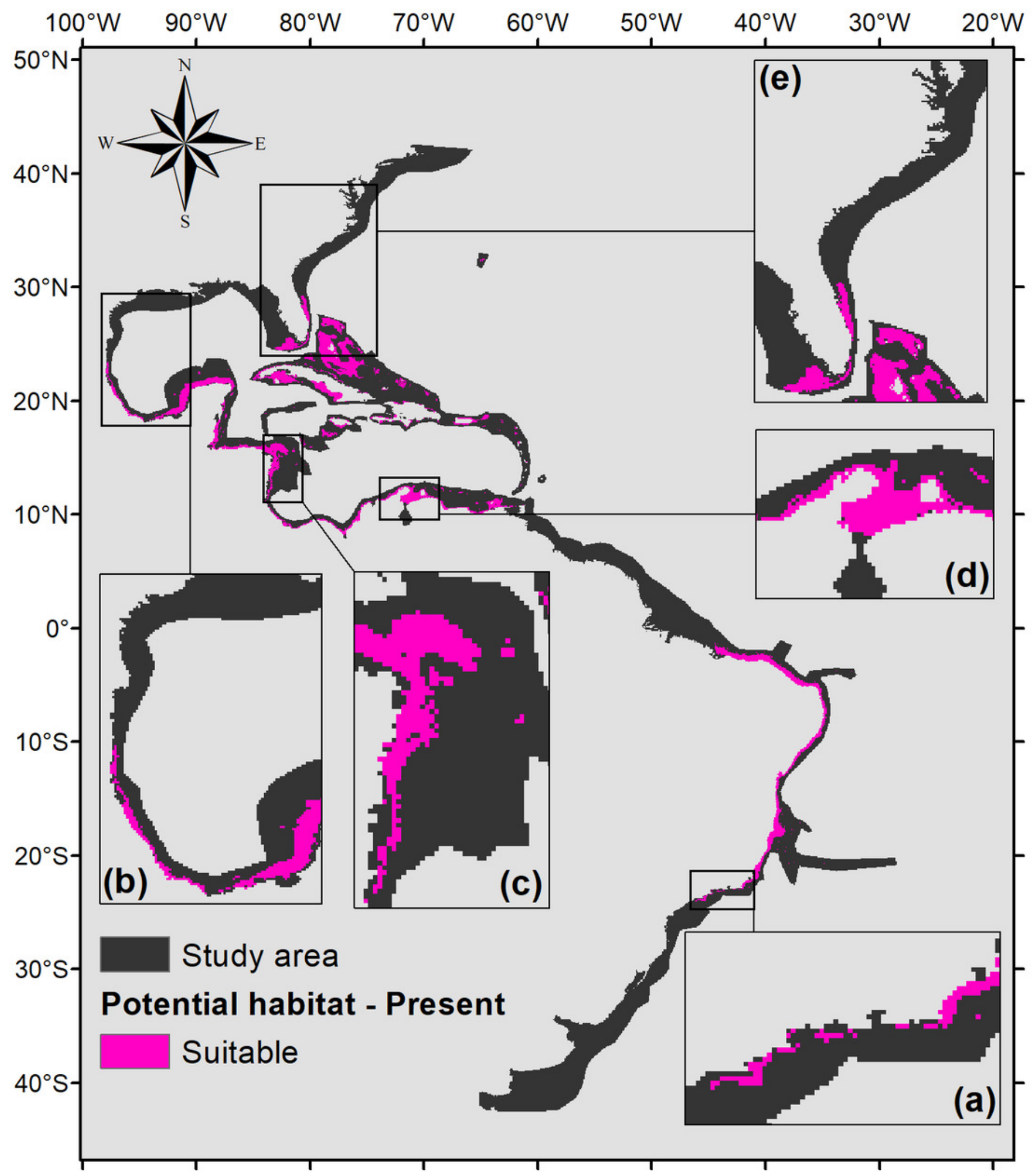




\section{Figure 4}

Suitable habitat for $P$. caribaeorum for the year 2100 under the RCP 2.6 climate scenario

Suitable habitat for $P$. caribaeorum for the year 2100 under the RCP 2.6 climate scenario, which includes regions with retained, new, and lost suitability compared with the present. Details for (a) southeastern Brazil, (b) southern Gulf of Mexico, (c) southwestern Caribbean, (d) southern Caribbean, and (e) Floridian regions. 


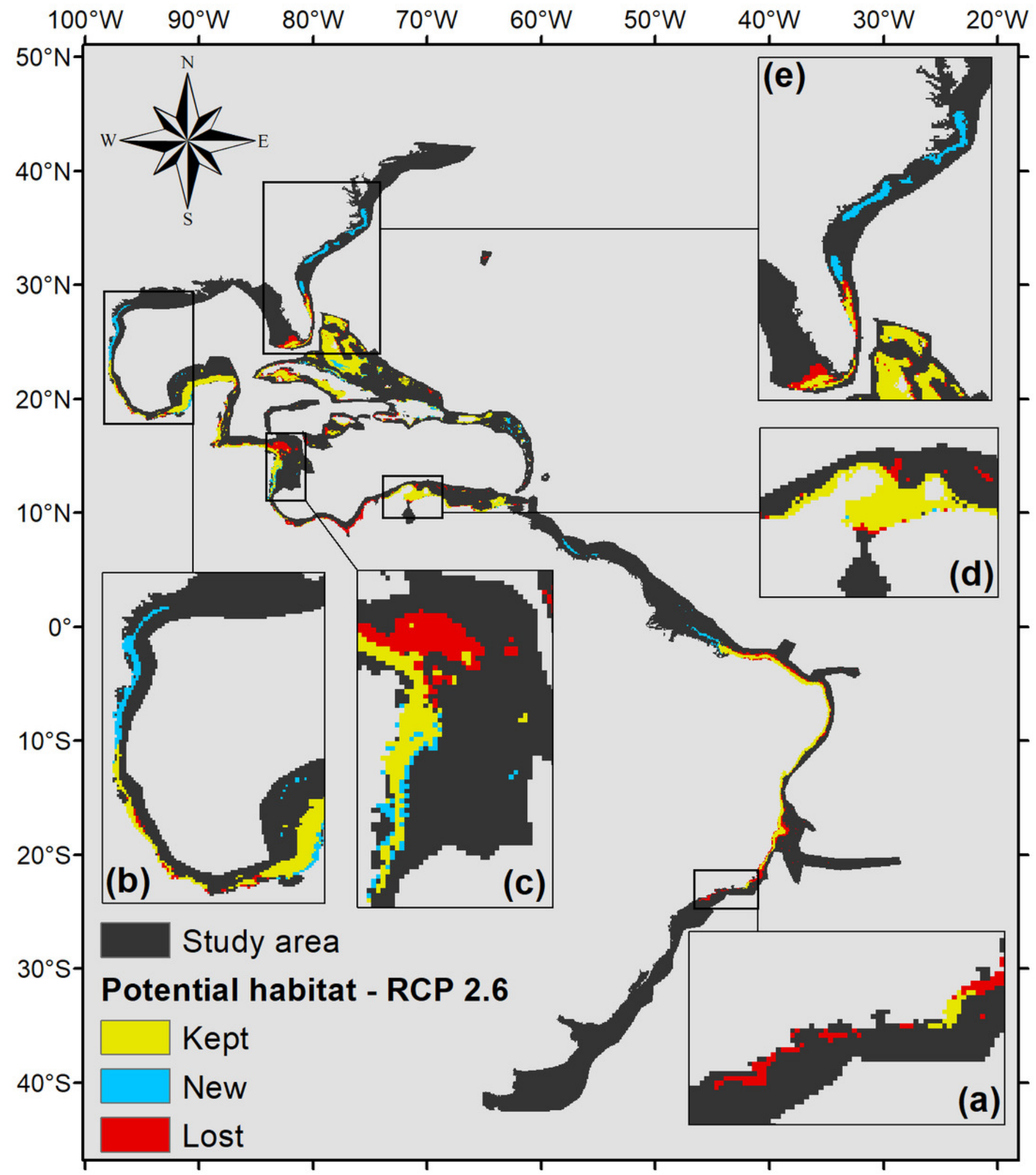




\section{Figure 5}

Habitat suitability map for $P$. caribaeorum in the year 2100 under the RCP 4.5 climate scenario.

The map includes regions with retained, new, and lost suitability compared with the present.

Details for (a) southeastern Brazil, (b) southern Gulf of Mexico, (c) southwestern Caribbean, (d) southern Caribbean, and (e) Floridian regions. 


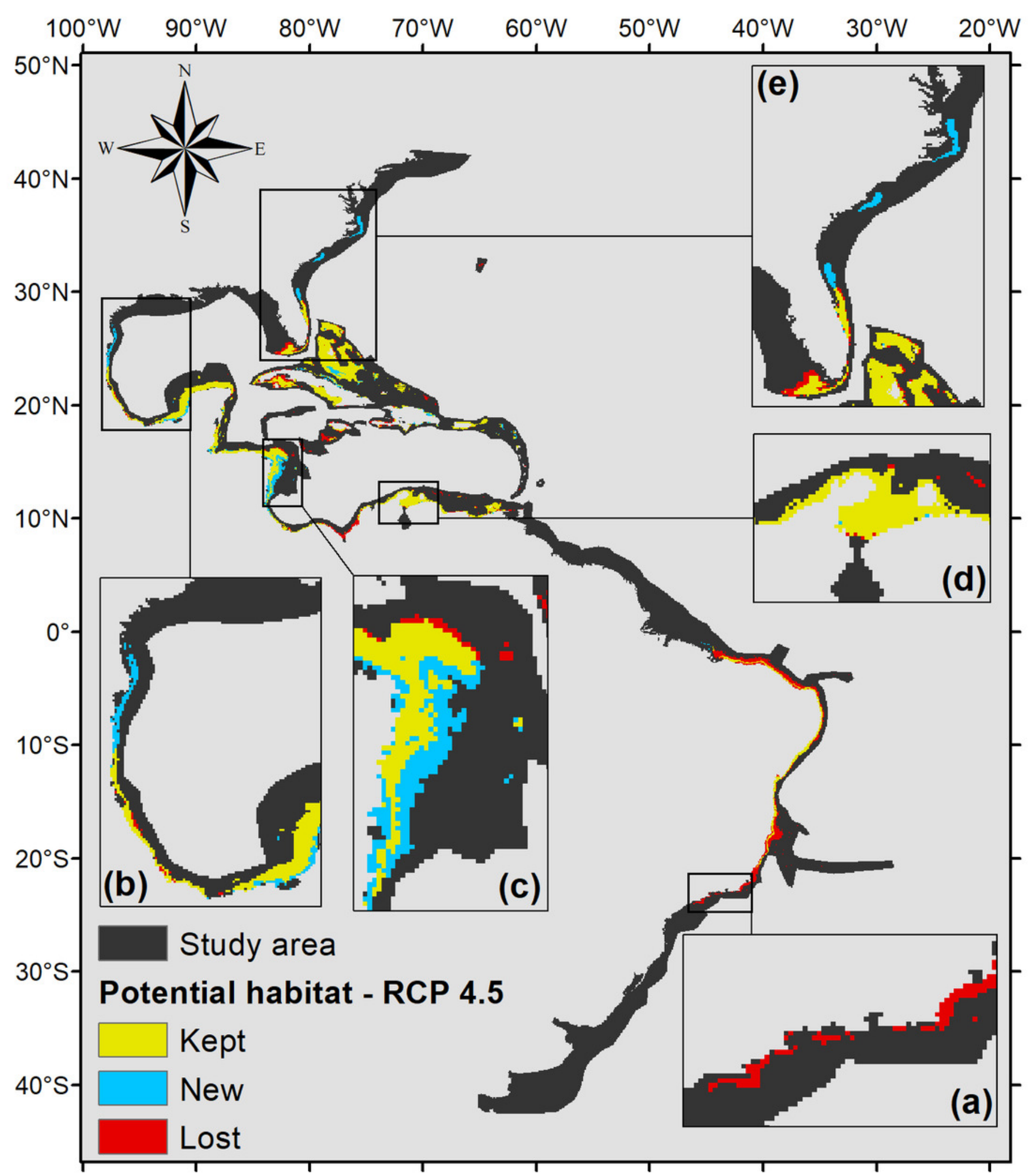




\section{Figure 6}

Habitat suitability map for $P$. caribaeorum in the year 2100 under the RCP 8.5 climate scenario.

The map includes regions with retained, new, and lost suitability compared with the present.

Details for (a) southeastern Brazil, (b) southern Gulf of Mexico, (c) southwestern Caribbean, (d) southern Caribbean, and (e) Floridian regions. 


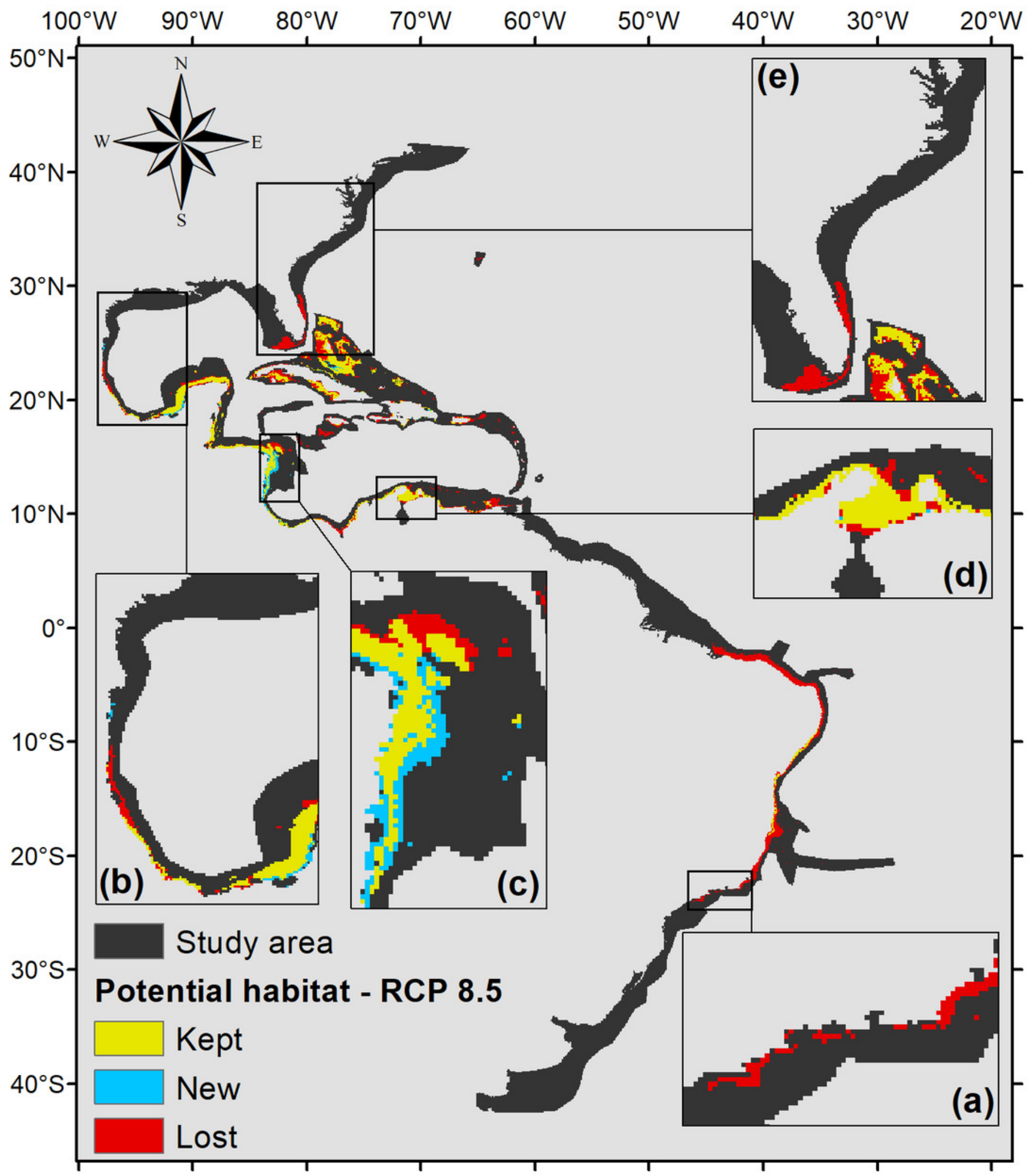


Figure 7

Map of potential habitat for P. caribaeorum in the year 2100 under any climate scenario (pink)

Details for (a) southeastern Brazil, (b) southern Gulf of Mexico, (c) southwestern Caribbean, (d) southern Caribbean, and (e) Floridian regions. 


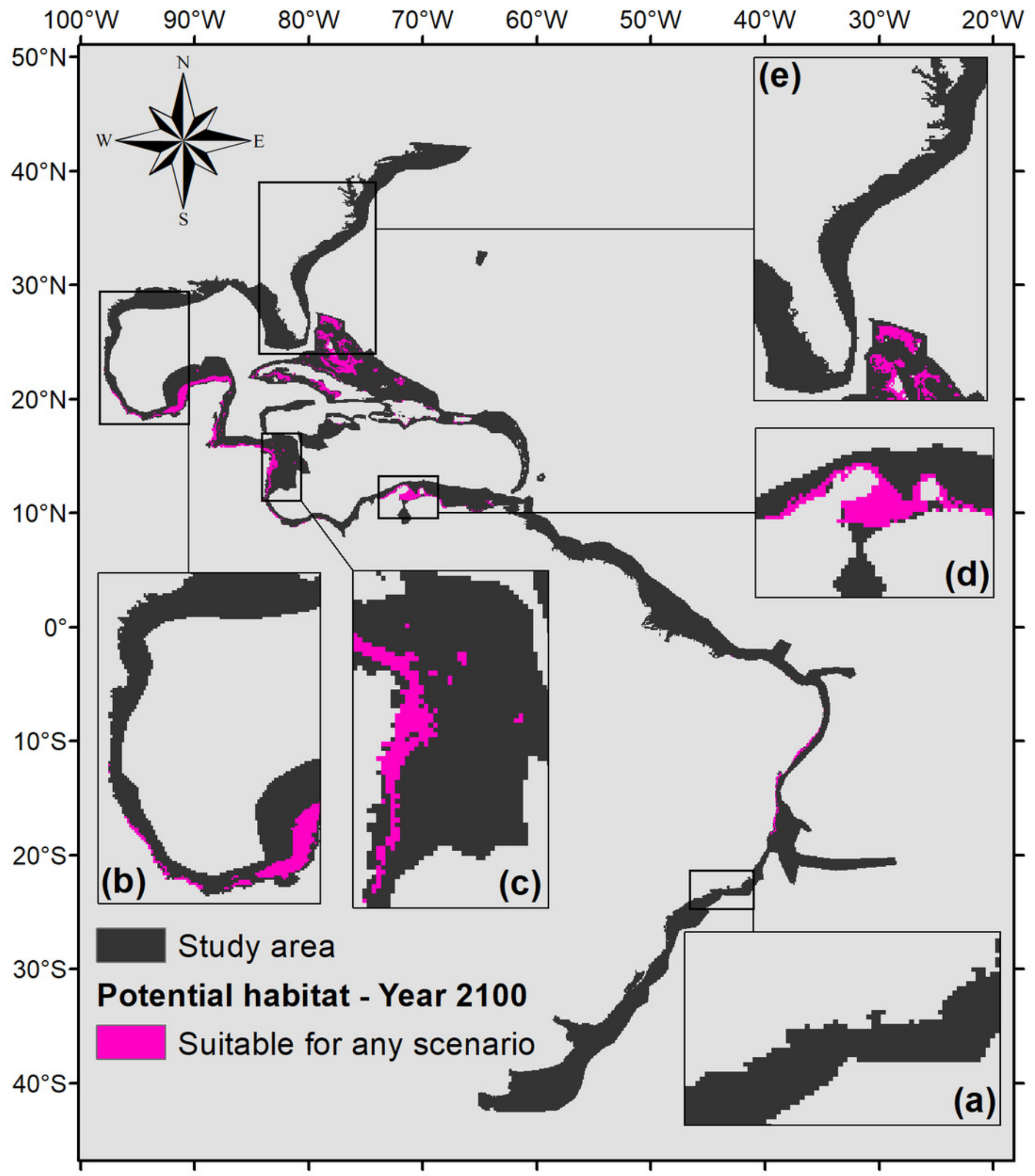




\section{Table $\mathbf{1}$ (on next page)}

Details about the variables retrieve from Bio-Oracle dataset and the layers kept in the final distribution model for $P$. caribaeorum. 


\begin{tabular}{|c|c|c|c|c|c|}
\hline Variables & Unit & Measurement & $\begin{array}{l}\text { Measurement } \\
\text { transformations }\end{array}$ & $\begin{array}{l}\text { Number of } \\
\text { layers }\end{array}$ & $\begin{array}{l}\text { Kept in the final } \\
\text { model }\end{array}$ \\
\hline Calcite concentration & $\mathrm{mol} / \mathrm{m}^{3}$ & Remote sensor & Average & 1 & $\begin{array}{l}\text { Average } \\
\text { concentration }\end{array}$ \\
\hline Chlorophyll- $a$ concentration & $\mathrm{mg} / \mathrm{m}^{3}$ & Remote sensor & $\begin{array}{l}\text { Average, minimum, maximum } \\
\text { and range }\end{array}$ & 4 & $\begin{array}{l}\text { Maximum } \\
\text { concentration }\end{array}$ \\
\hline Cloud coverage & $\%$ & Remote sensor & $\begin{array}{l}\text { Average, minimum and } \\
\text { maximum }\end{array}$ & 3 & - \\
\hline Difusive atenuation coeficient (490 nm) & $1 / \mathrm{m}$ & Remote sensor & $\begin{array}{l}\text { Average, minimum and } \\
\text { maximum }\end{array}$ & 3 & - \\
\hline Photosynthetic available radiation & Einstein $/ \mathrm{m}^{2} /$ day & Remote sensor & Average and maximum & 2 & - \\
\hline Air temperature above sea surface & ${ }^{\circ} \mathrm{C}$ & Remote sensor & $\begin{array}{l}\text { Average, minimum, maximum } \\
\text { and range } \\
\text { Average, minimum, maximum }\end{array}$ & 4 & - \\
\hline Sea surface temperature & ${ }^{\circ} \mathrm{C}$ & Remote sensor & and range & 4 & Range \\
\hline Dissolved oxygen & $\mathrm{ml} / 1$ & In situ & Diva interpolation & 1 & - \\
\hline Nitrate & $\mu \mathrm{mol} / 1$ & In situ & Diva interpolation & 1 & - \\
\hline $\mathrm{pH}$ & - & In situ & Diva interpolation & 1 & Diva interpolation \\
\hline Phosphate & $\mu \mathrm{mol} / 1$ & In situ & Diva interpolation & 1 & - \\
\hline Salinity & PSU & In situ & Diva interpolation & 1 & Diva interpolation \\
\hline Silicate & $\mu \mathrm{mol} / 1$ & In situ & Diva interpolation & 1 & - \\
\hline
\end{tabular}

1

2 Table 1: Details about the variables retrieve from Bio-Oracle dataset and the layers kept in the final distribution model for $P$.

3 caribaeorum. 